\title{
Hydrochemistry as a tool for interpreting brine origin and chemical equilibrium in oilfields: Zubair reservoir southern Iraq case study
}

\author{
Salih Muhammad Awadh ${ }^{1}$ (D) Muhanad R. Al-Auweidy ${ }^{2} \cdot$ Abdullah A. Al-Yaseri $^{2}$
}

Received: 7 November 2018 / Accepted: 21 March 2019 / Published online: 1 April 2019

(c) The Author(s) 2019

\begin{abstract}
The oil reservoir brines are very common geological fluids coexisting with hydrocarbons. The chemistry of brines is a powerful tool for determining the brine evolution and its origin, constraining fluid flow at the basin and predicting reservoir scales. This study targeted the Zubair brines in seven oilfields and investigated the geochemical evolution of brine compositions. The composition of the Zubair brine is characterized by the high average of TDS $(219,408 \mathrm{mg} / \mathrm{l})$. The contribution of cations as epm\% are $\mathrm{Na}(73.7), \mathrm{Ca}(17.32), \mathrm{Mg}$ (7.45), and $\mathrm{K}(1.27)$, while anions contribute as $\mathrm{Cl}(99.6), \mathrm{SO}_{4}(0.23)$, $\mathrm{HCO}_{3}(0.08)$, and $\mathrm{CO}_{3}(0.005)$. The Zubair brines are of $\mathrm{Na}-\mathrm{Ca}-$ chloride type, whereas sodium content is 6.3 times greater than seawater; $\mathrm{Ca}$ and $\mathrm{Mg}$ contents are thirty-four and three times greater, respectively, while $\mathrm{Cl}$ is seven times greater. The $\mathrm{SO}_{4}$ ion is depleted to 0.16 , due to a biodegradation. The salinity of the Zubair brine is six times more than that of seawater. The Zubair brines are characterized by an acidic $\mathrm{pH}(5.24-5.68)$ with a specific gravity of 1.1436 , hydrocarbon saturation in pore spaces of $39 \%$, and water saturation of $61 \%$. The mineral saturation model indicates that Zubair brines are unsaturated. The predicted hypothetical salts are $\mathrm{NaCl}(76 \%), \mathrm{CaCl}_{2}(15 \%)$, and $\mathrm{MgCl}_{2}(7.5 \%)$. The salts $\mathrm{Ca}\left(\mathrm{HCO}_{3}\right)_{2}, \mathrm{CaSO}_{4}$, and $\mathrm{KCl}$ together form only $1.6 \%$. The Zubair brines are characterized by $\mathrm{Cl} / \mathrm{Br}$ (305) in average, greater than that of seawater (289) confirming the fluids (brines and hydrocarbons) migrated upwards from Sargelu Formation to Zubair reservoir through fractures and cracks in Gotnia Formation.
\end{abstract}

Keywords Salinity $\cdot$ Oilfield water $\cdot$ Mineral saturation index $\cdot$ Zubair brines $\cdot \mathrm{Cl} / \mathrm{Br}$

\section{Introduction}

This study was conducted on the oilfield waters of the Zubair reservoir in seven oilfields in southern Iraq. Zubair Formation (Barremian-Hauterivian) is considered as an important formation in Iraq (Buday and Jassim 1980), which is the most productive oil reservoir. It is prevalently composed of terrigenous clastic as alternative layers from dominant sandstone succession with some shale and oil in the southern Iraqi fields

Salih Muhammad Awadh

salihauad2000@yahoo.com;

salihauad2000@scbaghdad.edu.iq

Muhanad R. Al-Auweidy

muhannedaljebory@yahoo.com

Abdullah A. Al-Yaseri

spcbasrah@yahoo.com

1 Department of Geology, College of Science, University of Baghdad, POB 47182, Baghdad, Iraq

2 Basrah Oil Company, Basrah, Iraq
(Aqrawi et al. 2010) and an important huge siliciclastic reservoir (Ibrahim 2001). It is considered as a fair potential source rock based on $0.2-2.6 \mathrm{wt} \% \mathrm{TOC}$ in the shale layers, where the major source of kerogen in the Zubair reservoir is a result of migration and accumulation from the Jurassic-Lower Cretaceous source rocks to different Cretaceous reservoir traps (AlAmeri et al. 2011). The Zubair oilfield water is of marine origin and has been increasingly salted by interaction with the reservoir rocks (Awadh 2018). Oilfield water is brine that occurs naturally within the pores of reservoir sedimentary rock associated with the oil and gas and is free to move under appropriate hydrodynamic conditions. Oilfield waters have not received much interest, as the studies have focused on the crude oil in terms of organic geochemistry and petroleum system. Thus, the role of the Zubair oilfield water in the oil production is negligible. The physico-chemical properties of the oilfield waters impact petrophysical properties of reservoir. The chemistry of oilfield brines can help to predict pressure distribution and then determine the best-drilling sites for future exploration (Awadh 2018; Awadh et al. 2018). The fluid flow direction which is 
an essential parameter for hydrocarbons can be suggested by hydrochemistry (Brouwer and Jansen 2004). When the concentration of $\mathrm{Cl}$ reaches $180,000 \mathrm{ppm}$, the halite is precipitated but the $\mathrm{Br}$ partitions and holds in the solution (Walter et al. 2015), so the halite is relatively depleted in $\mathrm{Br}$. The $\mathrm{Cl} / \mathrm{Br}$ ratio in the oilfield brines can be used as a function of brine origin whether it is of marine origin or mixed with dissolved evaporite water. It is inferring the geochemical provenance of different groundwaters (Freeman 2007). This study is going to describe the physico-chemical characteristics of the Zubair oilfield brines, determine the distribution of salinity and its origin, estimate the brine equilibrium state and hypothetical salts.

\section{The study area and geology}

The study area is located in Basrah, southern Iraq (Fig. 1). It is relatively of flat terrain with a gradient of less than $10 \mathrm{~cm}$ per kilometer. Tectonically, it is located in the southern part of the near platform flank of Mesopotamian foredeep (Aqrawi et al. 2010), within the Zubair subzone which is a part of the Stable Shelf (Jassim and Goff 2006). The oilfields studied have N-S trending folds in the Mesopotamian basin. The present research deals with salinity of the Ratawi (Rt), Luhais (Lu), Suba (Su), Rumaila North (R), Rumaila South $(\mathrm{Ru})$, Zubair (Zb) and Nahr Umer (NR) oilfields within Zubair reservoir (Fig. 1). The Zubair Formation is equivalent to Gadvan Formation in Iran and to Biyadh Formation in the Saudi Arabia and to Zubair in Kuwait (AL-Husseini 1997). The Zubair (Barremian-Early Albian) (Al-Ameri et al. 2011) is 301-381 m thick in southern Iraq (Ali and Nasser 1989). In the south of Iraq and Kuwait, it is overlain by the Aptian Shuaiba limestone Formation and is underlain by the Valanginian-Hauterivian Ratawi Limestone Formation; both formation contacts are gradational and conformable (Jassim and Goff 2006). In some parts of the Salman Zone, it overlies unconformably the Sullay Formation (Buday and Jassim 1980). The Zubair Formation is considered as

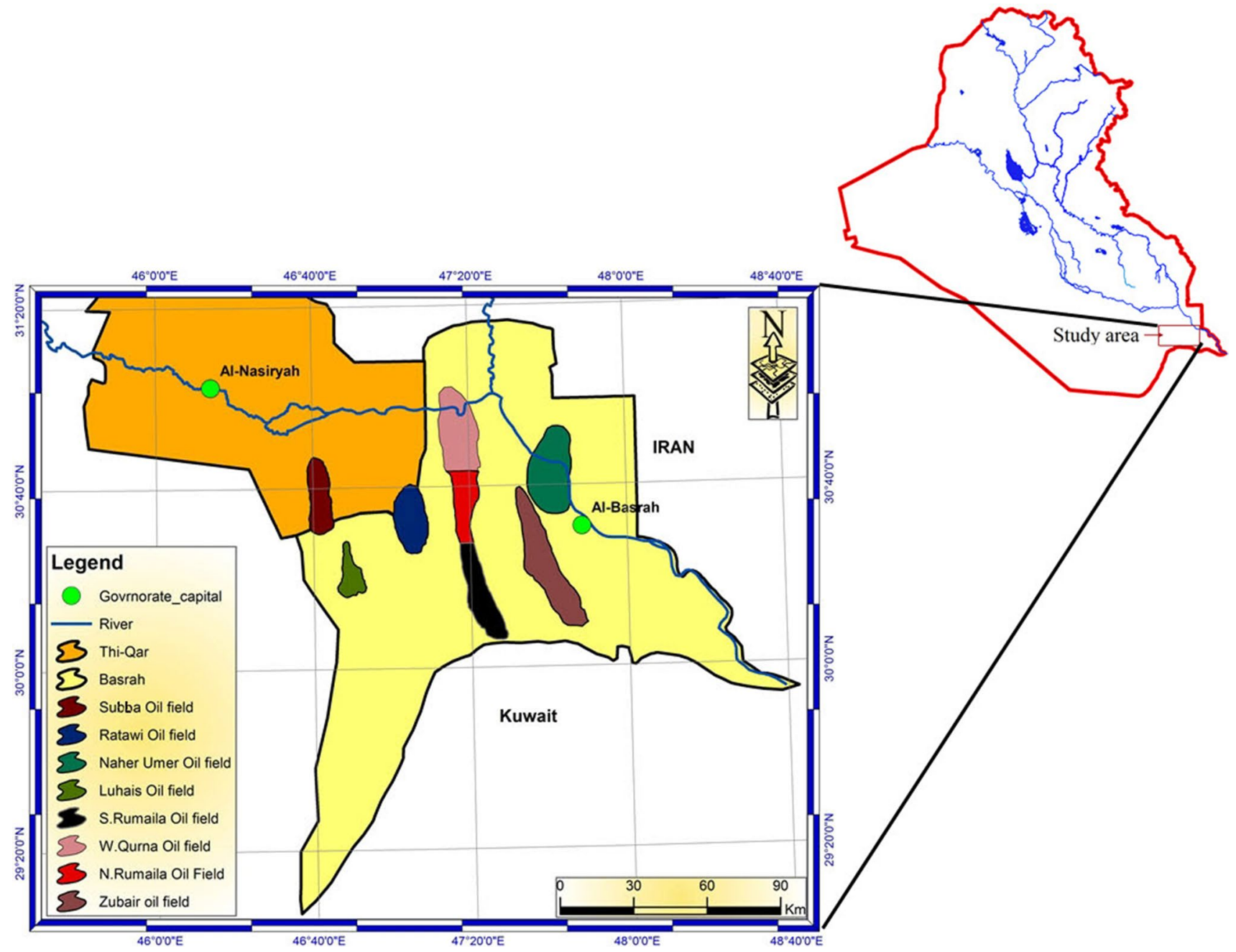

Fig. 1 Location map shows the oilfields studied 
a prograding delta (Ziegler 2001). After the uplifting in the west, deltaic sediments derived from the erosion of the Arabian Shield and the stable shelf (Al-Sharhan and Nairn 1997). The uplifting results from the Late Kimmerian movement (Al-Fares et al. 1998) and thermal doming and rifting eastern Africa (Giraud and Maurin 1992). The deposition is contemporaneous with the opening Neo-Tethys Ocean in the east of Arabian plate in the Early Cretaceous. It is composed of flovio-deltaic, deltaic and huge amount of marine sandstones (Aqrawi et al. 2010). The Zubair Formation is divided mainly into five lithological units in southern Iraq (Jasim et al. 2006) representing the succession sandstone and shale (Van Bellen et al. 1959). The shale layer in Zubair Formation is a primary seal that envelops the reservoir (Sharland et al. 2001). In southern Iraq, the Zubair Formation overlies the Jurassic-Early Cretaceous formations, which include Sargelu, Najmah, Gotnia, Sulaiy Yamama and Ratawi (Aqrawi et al. 2010) (Fig. 2).

\section{Materials and methods}

Seventy-five oilfield water samples from seventy-five oil wells were collected by the Basrah Oil Company (BOC). Nineteen samples were from $R$, twenty samples from the $\mathrm{Ru}$, four samples from $\mathrm{NR}$, eight samples from $\mathrm{Lu}$, two samples from Rt and six samples from $\mathrm{Su}$. The $\mathrm{pH}$, electrical conductivity (EC) and total dissolved solids (TDS)

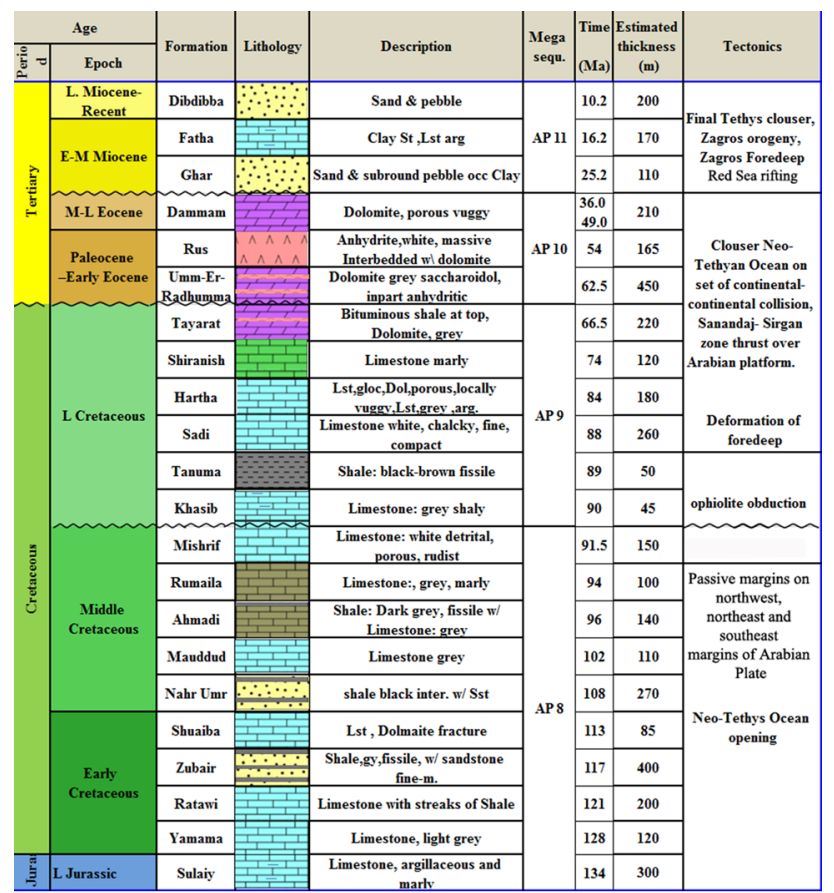

Fig. 2 Stratigraphic section of the Zubair oilfield (Jafar 2010) were measured in the field by using HANNA, type H19811 apparatus. The water was separated from the oil-water emulsion directly in the field by the accumulation of the water at a dead-end extraction line, facilitated by differences in density. Water samples were filtered to remove contaminated particle and drilling mud and then acidified with $\mathrm{HNO}_{3}$ (Ultrex) to $\mathrm{pH}<2$. The collected water samples were stored in clean polyethylene bottles of 11 size, filled to expel air and then tightly closed. The water samples were analyzed for the main cations ( $\mathrm{Na}, \mathrm{Ca}, \mathrm{Mg}$ and $\mathrm{K}$ ), main anions $(\mathrm{Cl}$ and $\mathrm{SO}_{4}$ ) and $\mathrm{Br}$ using analytical methods proposed by the BOC with acceptable analytical accuracy. The salinity maps were drawn using Surfer 15 software to clarify the fluid flow path. Hydrochemical formula (Kurlov formula), a useful method to display the primary characterization of the water chemistry (Zaporozec 1972), was applied by the following equation:

$\mathrm{TDS}_{\mathrm{mg} / 1} \frac{\text { Anions (epm\% ) in descending order }}{\text { Cations }(\mathrm{epm} \%) \text { in descending order }} \mathrm{pH}$

All concentrations of cation and anion unit are in epm\%, TDS in gm/l. The concentrations (epm) less than $15 \%$ were ignored. In this regard, Adams et al. (2001) pointed to the importance of identifying water quality in the knowledge of hydrochemical processes in the course of water movement. The version 1 of AquaSal Chem (Awadh 2012) software program was used for computing the hydrochemical formula and described the water type. Geochemistry softwares AqQA and RockWorks17 are used for the identification of water class by Piper, Schoeller and Stiff diagrams. The mineral saturated index and mineral precipitation model was simulated using the PHREEQC software. The hypothetical salts that may be precipitated from the Zubair brines were calculated based on Collins (1975).

\section{Results and discussion}

\section{Reservoir hydrochemistry}

The statistical hydrochemical results of Zubair brines are given in Table 1. The Zubair oilfield waters have TDS exceeding $200000 \mathrm{ppm}$ in average dominated by $\mathrm{Na}$ and $\mathrm{Cl}$ ions. The $\mathrm{Na}, \mathrm{Ca}$ and $\mathrm{Cl}$ ions compose of more than $97 \%$ of the total TDS, where ions descended as $\mathrm{Na}^{+}>\mathrm{Ca}^{2+}>\mathrm{Mg}^{2+}>\mathrm{K}^{+}$and $\mathrm{Cl}^{-}>\mathrm{SO}_{4}{ }^{2-}>\mathrm{HCO}_{3}{ }^{-}$.

The Na content is six times greater than seawater and varies within a range restricted between 71,340 and 64,295 ppm in Rt and Lu oilfields, respectively. It makes up over $77 \%$ by mass of the cations in the Zubair oilfield water. The Na availability in the oilfields is attributed to the long-term water trapping period and sodium solubility. Faure (1986) pointed 
Table 1 Statistical results of Zubair brines in oilfields studied compared to seawater

\begin{tabular}{|c|c|c|c|c|c|c|c|c|c|c|c|c|c|c|c|}
\hline Field & Unit & $\mathrm{Na}$ & $\mathrm{Ca}$ & $\mathrm{Mg}$ & $\mathrm{K}$ & $\mathrm{Cl}$ & $\mathrm{SO}_{4}$ & $\mathrm{HCO}_{3}$ & $\mathrm{pH}$ & $A^{\mathrm{a}}$ & Decision & TDS & $S \%$ & $S_{\mathrm{W}} \%$ & $S_{\mathrm{H}} \%$ \\
\hline \multirow[t]{3}{*}{$\mathrm{Zb}$} & ppm & 65,599 & 14,321 & 3105 & 1822 & 133,037 & 391 & 207 & 5.62 & & & 212,209 & 240 & 0.61 & 0.39 \\
\hline & epm & 2852 & 716 & 259 & 47 & 3801 & 8 & 3 & & 0.79 & Accepted & & & & \\
\hline & epm $\%$ & 74 & 18 & 7 & 1 & 99.70 & 0.21 & 0.09 & & & & & & & \\
\hline \multirow[t]{3}{*}{$\mathrm{Ru}$} & ppm & 67,068 & 14,659 & 3675 & 1920 & 140,317 & 389 & 120 & 5.29 & & & 232,206 & 257 & 0.61 & 0.39 \\
\hline & epm & 2916 & 733 & 306 & 49 & 4009 & 8 & 2 & & -0.18 & Accepted & & & & \\
\hline & epm $\%$ & 73 & 18 & 8 & 1 & 99.75 & 0.20 & 0.05 & & & & & & & \\
\hline \multirow[t]{3}{*}{$\mathrm{R}$} & $\mathrm{ppm}$ & 63,846 & 14,224 & 3236 & 2095 & 130,065 & 388 & 156 & 566 & & & 216,603 & 231 & 0.61 & 0.39 \\
\hline & epm & 2776 & 711 & 270 & 54 & 3716 & 8 & 3 & & 1.11 & Accepted & & & & \\
\hline & epm $\%$ & 73 & 19 & 7 & 1 & 99.71 & 0.22 & 0.07 & & & & & & & \\
\hline \multirow[t]{3}{*}{ NR } & ppm & 65,054 & 11,786 & 2854 & 1656 & 124,868 & 463 & 450 & 6.0 & & & 198,023 & 225 & 0.60 & 0.40 \\
\hline & epm & 2828 & 589 & 238 & 42 & 3568 & 10 & 7 & & 1.56 & Accepted & & & & \\
\hline & epm $\%$ & 76 & 16 & 6 & 1 & 99.53 & 0.27 & 0.21 & & & & & & & \\
\hline \multirow[t]{3}{*}{$\mathrm{Lu}$} & ppm & 64,295 & 14,232 & 3769 & 2246 & 122,187 & 538 & 87 & 5.97 & & & 211,926 & 221 & 0.56 & 0.41 \\
\hline & epm & 2806 & 712 & 314 & 58 & 3455 & 11 & 1 & & 5.73 & Accepted & & & & \\
\hline & epm $\%$ & 72 & 18 & 8 & 1 & 99.64 & 0.32 & 0.04 & & & & & & & \\
\hline \multirow[t]{3}{*}{$\mathrm{Su}$} & ppm & 66,192 & 14,138 & 3625 & 2139 & 129,008 & 441 & 101 & 5.42 & & & 209,534 & 233 & 0.61 & 0.39 \\
\hline & epm & 2995 & 703 & 277 & 48 & 4017 & 5 & 2 & & -0.02 & Accepted & & & & \\
\hline & epm $\%$ & 74 & 17 & 7 & 1 & 99.82 & 0.13 & 0.05 & & & & & & & \\
\hline \multirow[t]{3}{*}{ Rt } & ppm & 71,340 & 12,825 & 4475 & 2060 & 140,375 & 485 & 40 & 5.85 & & & 203,700 & 253 & 0.61 & 0.39 \\
\hline & epm & 3102 & 641 & 373 & 53 & 4011 & 10 & 1 & & 1.80 & Accepted & & & & \\
\hline & epm $\%$ & 74 & 15 & 9 & 1 & 99.73 & 0.25 & 0.02 & & & & & & & \\
\hline Max & ppm & 71,340 & 14,659 & 4475 & 2246 & 140,610 & 538 & 450 & 6.0 & & & 232,206 & 257 & 0.61 & 0.40 \\
\hline Av. & & 66,583 & 13,730 & 3492 & 1954 & 133,066 & 416 & 168 & 5.69 & & & 212,029 & 237 & 0.60 & 0.39 \\
\hline Min & & 63,846 & 11,786 & 2854 & 1656 & 122,187 & 260 & 40 & 5.29 & & & 198,023 & 221 & 0.59 & 0.39 \\
\hline Av. & epm $\%$ & 74 & 18 & 7 & 1 & 100 & 0 & 0 & & & & & & & \\
\hline SD & & 2517 & 1039 & 533 & 203 & 7045 & 57 & 136 & & & & 10,800 & & & \\
\hline \multirow[t]{3}{*}{$\mathrm{SW}^{\mathrm{b}}$} & $\mathrm{ppm}$ & 10,500 & 400 & 1350 & 380 & 19,000 & 2600 & 142 & 8.8 & & & 35,000 & 35 & & \\
\hline & epm & 686.48 & 290.99 & 50.10 & 3922 & 8.67 & 2.76 & 3813.3 & & & & & & & \\
\hline & epm $\%$ & 76 & 3 & 19 & 2 & 90.57 & 9.04 & 0.39 & & & & & & & \\
\hline
\end{tabular}

${ }^{\mathrm{a}} A$ accuracy

${ }^{\mathrm{b}} S W$ seawater (Edmund 2009)

out that the high sodium content in the brines related to its high mobility in the hydrosphere. The Ca content is thirty times greater than seawater varying within a range restricted between 11,786 and 14,436 ppm in NR and $R$ oilfields, respectively. The availability of $\mathrm{Ca}$ is a function of reservoir dissolution, and calcium carbonate scale may be formed when being oversaturated, where it is a most common scale found in plugged oilfield reservoirs (Collins 1975). The lack of $\mathrm{Mg}$ in brine is linked directly with the dolomitization (Fleischer 1962). A twice $\mathrm{Mg}$ as much as seawater was found, where it ranges between 2854 and 4475 ppm in NR and Rt oilfields, respectively. The high $\mathrm{Mg}$ content indicates a low rate of dolomitization and dissolving of $\mathrm{Mg}$-bearing minerals. Potassium content increases in aqueous solutions under high temperature until the sylvite precipitates (Mason 1966). Potassium is found as five times as much as seawater ranging between 1656 and $2246 \mathrm{ppm}$ in NR and Lu oilfields, respectively. Shale is a responsible agent of $\mathrm{K}$, particularly where containing illite. Chloride ion makes up over $99 \%$ by mass of the anions in the Zubair oilfield water; it concentrated seven times as much as seawater, varying from 122,187 to $140,610 \mathrm{ppm}$ in $\mathrm{Lu}$ and Su oilfield, respectively. The high chloride content is attributed to difficulties absorbing on clay or other mineral surfaces. Sulfate is consumed by reduction to form dissolved sulfide by bacterial biogenic processes as well as by sulfate precipitation producing $\mathrm{H}_{2} \mathrm{~S}$. Sulfates in oil reservoirs have a greater importance, resulting in the possibility it links with other ions such as $\mathrm{Sr}$ and $\mathrm{Ba}$ composes of sulfate precipitate is insoluble such as celestite and barite. These components lead to reservoir damage as plug pores and thus prevent the fluid passage (Al-Atabi 2009; Awadh et al., 2014; Awadh, 2018; Awadh et al. 2018). The sulfate content is lower than its content in seawater (900 ppm) having range of 260-538 ppm in Lu and Su oilfields, respectively. The bicarbonates content varies between 40 and 450 ppm in Rt and NR oilfields, respectively, which 
Table 2 Hydrochemical formula of the Zubair brines in the studied oilfields compared to seawater

Fig. 3 Sulin diagram shows Zubair brines occupying the field of old marine water

\begin{tabular}{|c|c|c|}
\hline Oilfields & Hydrochemical formula & Water type \\
\hline Zubair (Zb) & $\operatorname{TDS}_{(218.482) \mathrm{mg} / 1} \frac{\mathrm{Cl}_{(99.70)}}{\mathrm{Na}_{(73.63)} \mathrm{Ca}_{(18.49)}} \mathrm{pH}_{(5.62)}$ & $\mathrm{Na}-\mathrm{Ca}-$ chloride \\
\hline Rumaila N. (R) & $\operatorname{TDS}_{(221.010) \mathrm{mg} / 1} \frac{\mathrm{Cl}_{(99.71)}}{\mathrm{Na}_{(72.85)} \mathrm{Ca}_{(18.67)}} \mathrm{pH}_{(5.68)}$ & $\mathrm{Na}-\mathrm{Ca}-$ chloride \\
\hline Rumaila S. (Ru) & $\operatorname{TDS}_{(221.000) \mathrm{mg} / 1} \frac{\mathrm{Cl}_{(99.74)}}{\mathrm{Na}_{(72.82)} \mathrm{Ca}_{(18.3)}} \mathrm{pH}_{(5.47)}$ & $\mathrm{Na}-\mathrm{Ca}-$ chloride \\
\hline Nhar Umer (NR) & $\operatorname{TDS}_{(207.130) m g / l} \frac{\mathrm{Cl}_{(99.52)}}{\mathrm{Na}_{(76.48)} \mathrm{Ca}_{(15.94)}} \mathrm{pH}_{(6.0)}$ & $\mathrm{Na}-\mathrm{Ca}-$ chloride \\
\hline Luhais $(\mathrm{Lu})$ & $\operatorname{TDS}_{(207.354) m g / l} \frac{\mathrm{Cl}_{(99.63)}}{\mathrm{Na}_{(72.15)} \mathrm{Ca}_{(18.3)}} \mathrm{pH}_{(5.97)}$ & $\mathrm{Na}-\mathrm{Ca}-$ chloride \\
\hline Suba $(\mathrm{Su})$ & $\operatorname{TDS}_{(229.133) \mathrm{mg} / 1} \frac{\mathrm{Cl}_{(99.81)}}{\mathrm{Na}_{(74.43)} \mathrm{Ca}_{(17.47)}} \mathrm{pH}_{(5.42)}$ & $\mathrm{Na}-\mathrm{Ca}-$ chloride \\
\hline Ratawi (Rt) & $\operatorname{TDS}_{(231.600) \mathrm{mg} / 1} \frac{\mathrm{Cl}_{(99.73)}}{\mathrm{Na}_{(74.41)} \mathrm{Ca}_{(15.38)}} \mathrm{pH}_{(5.85)}$ & $\mathrm{Na}-\mathrm{Ca}-$ chloride \\
\hline Average & $\operatorname{TDS}_{(219.110) \mathrm{mg} / 1} \frac{\mathrm{Cl}_{(99.74)}}{\mathrm{Na}_{(73.9)} \mathrm{Ca}_{(17.33)}} \mathrm{pH}_{(5.72)}$ & $\mathrm{Na}-\mathrm{Ca}-$ chloride \\
\hline Seawater & $\operatorname{TDS}_{(35.000) \mathrm{mg} / \mathrm{l}} \frac{\mathrm{Cl}_{(90.45)}}{\mathrm{Na}_{(76.24)} \mathrm{Mg}_{(18.79)}} \mathrm{pH}_{(8)}$ & $\mathrm{Na}-\mathrm{Mg}$-chloride \\
\hline
\end{tabular}

Sulin graph of zubair oilfield water

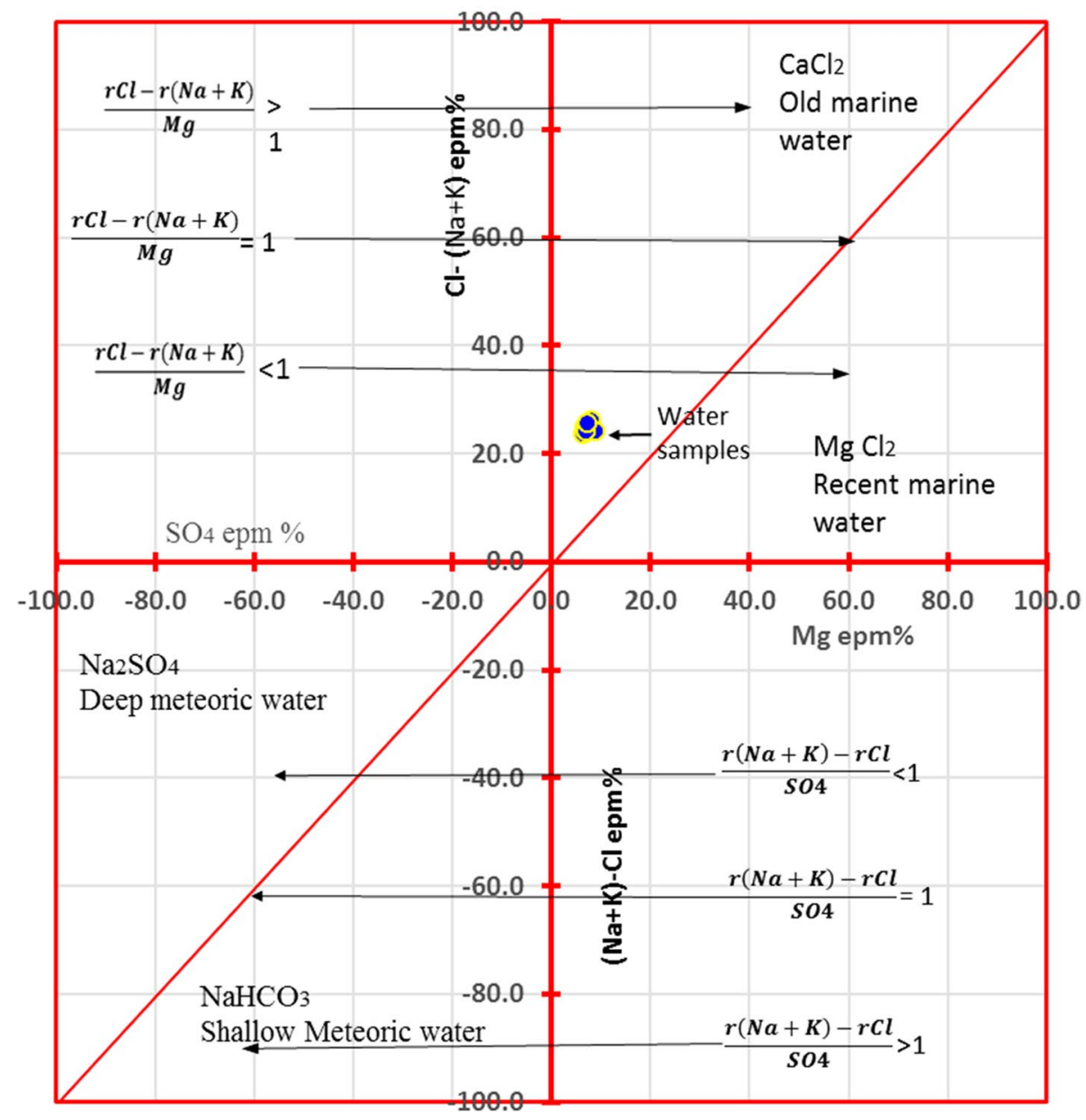


Table 3 Environment characteristic and water type depending Sulin coefficient

\begin{tabular}{|c|c|c|c|}
\hline Ratio & Coefficient & Water type & Environment characteristic \\
\hline \multirow[t]{2}{*}{$\frac{\mathrm{Na}+\mathrm{K}}{\mathrm{Cl}}>1$} & $\frac{(\mathrm{Na}+\mathrm{K})-\mathrm{Cl}}{\mathrm{SO}_{4}}>1$ & $\mathrm{NaHCO}_{3}$ & $\begin{array}{l}\text { Reduction oxidation, mostly wet freshwater lacustrine sedimentary facies, good sign of oil gas, } \mathrm{pH}>8 \text {, } \\
\text { alkaline water }\end{array}$ \\
\hline & $\frac{(\mathrm{Na}+\mathrm{K})-\mathrm{Cl}}{\mathrm{SO}_{4}}<1$ & $\mathrm{Na}_{2} \mathrm{SO}_{4}$ & $\begin{array}{l}\text { Surface water, continental environment, not conducive to the accumulation of oil and gas preservation, } \\
\text { poor closed environment reflection }\end{array}$ \\
\hline \multirow[t]{2}{*}{$\frac{\mathrm{Na}+\mathrm{K}}{\mathrm{Cl}}<1$} & $\frac{\mathrm{Cl}-(\mathrm{Na}+\mathrm{K})}{\mathrm{Mg}}>1$ & $\mathrm{CaCl}_{2}$ & $\begin{array}{l}\text { Closed reduction type, completely closed deep geological environment, a sign for good oil and gas, alter- } \\
\text { native groundwater and surface completely isolated without water }\end{array}$ \\
\hline & $\frac{\mathrm{Cl}-(\mathrm{Na}+\mathrm{K})}{\mathrm{Mg}}<1$ & $\mathrm{MgCl}_{2}$ & $\begin{array}{l}\text { Redox type, marine environment, the oil and ground is not connected, good sealing conditions, exist in oil } \\
\text { and gas field inside in most cases }\end{array}$ \\
\hline
\end{tabular}

Fig. 4 Schoeller classification of Zubair brines

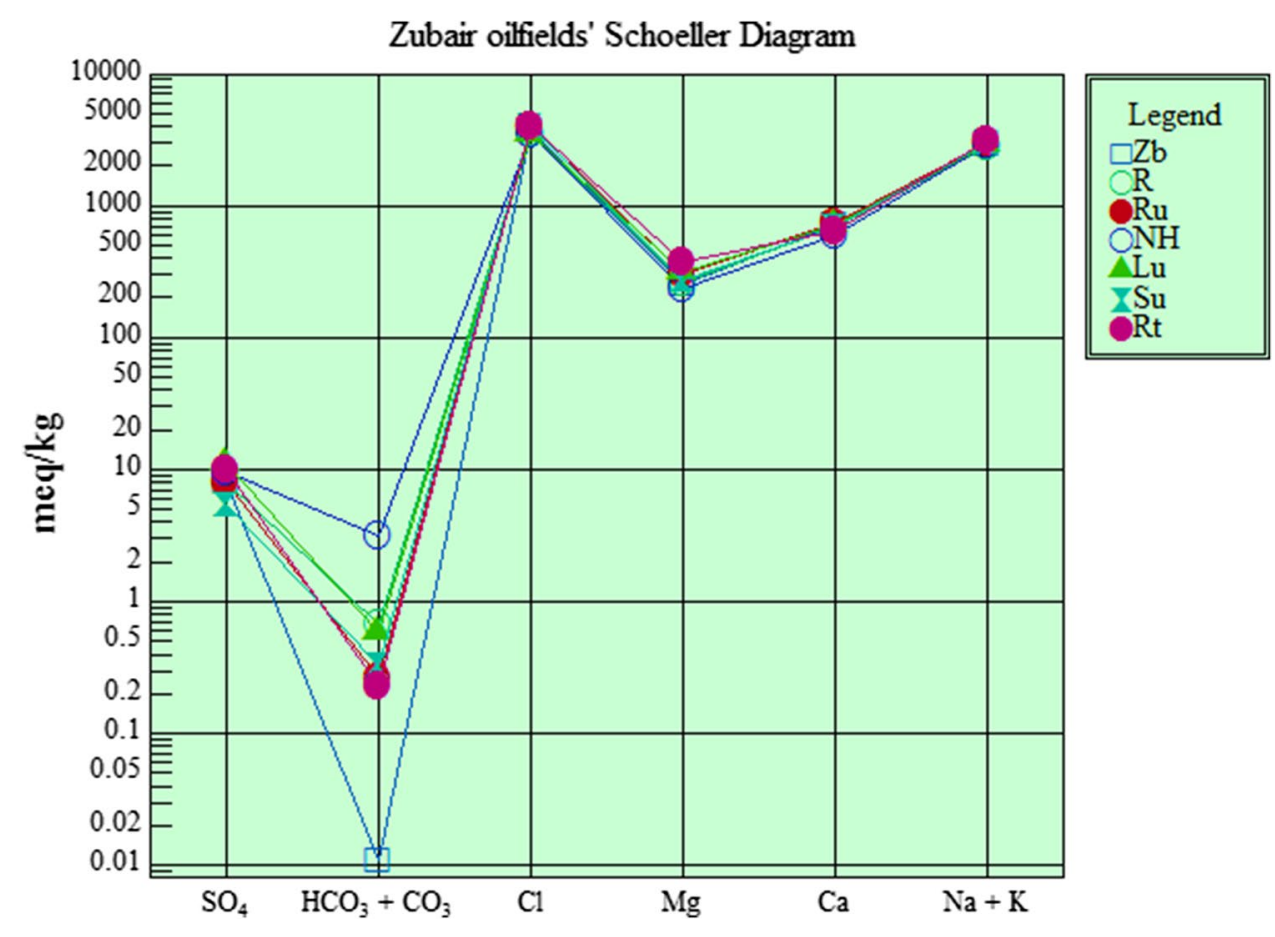

is modtlt coming from the dissolution of carbonate cement. The $\mathrm{Na}-\mathrm{Ca}$-chloride is a distinct facies that characterizes the Zubair reservoir in all oilfields (Table 2).

The averages of hydrochemical values of brines in each of Zubair oilfields were plotted on Sulin, Schoeller, Piper and stiff diagrams. The water type and environmental characteristics based on the ratio $(\mathrm{Na}+\mathrm{K}) / \mathrm{Cl}$ are inserted in Table 3 . Accordingly, it was confirmed that the Zubair brines are of chloride-calcium type originated from an old marine water in the confined basin dominated by $\mathrm{CaCl}_{2}$ salts (Fig. 3).

The Zubair brines in each oilfield are of similar composition characterized by chloride group of $\mathrm{Na}-\mathrm{Cl}$ family (Fig. 4). The $\mathrm{Na}$ and $\mathrm{Cl}$ are the predominant ions clearly much concentrated than in seawater, while sulfates and bicarbonates seem depleted. The Zubair brines seem to be hypersaline dominated by $\mathrm{Na}$ and $\mathrm{Cl}$ ions derived originally from marine water (Fig. 5a, b). The patterns of the Sulin diagram for both of Zubair and seawater are similar in shape while different in quantity (Fig. 5b).

\section{Equilibrium and potential salts}

The saturation index (SI) is used to reveal the solution tendency toward precipitation or dissolution and is given by the equation stated by Rao and Rao (2010):

$\mathrm{SI}=\log 10 \mathrm{IAP} / \mathrm{Ksp}$

When $\mathrm{IAP}=\mathrm{Ksp}, \mathrm{SI}=0$ saturated water with equilibrium mineral phase; IAP $<\mathrm{Ksp}$, SI $<0$ undersaturated water and mineral phase tends to dissolve; IAP $>\mathrm{Ksp}, \mathrm{SI}>0$ supersaturation water and mineral phase tends to precipitate.

The SI values indicate that the Zubair brines are unsaturated (Table 4 and Fig. 6), so ions prefer to remain in 


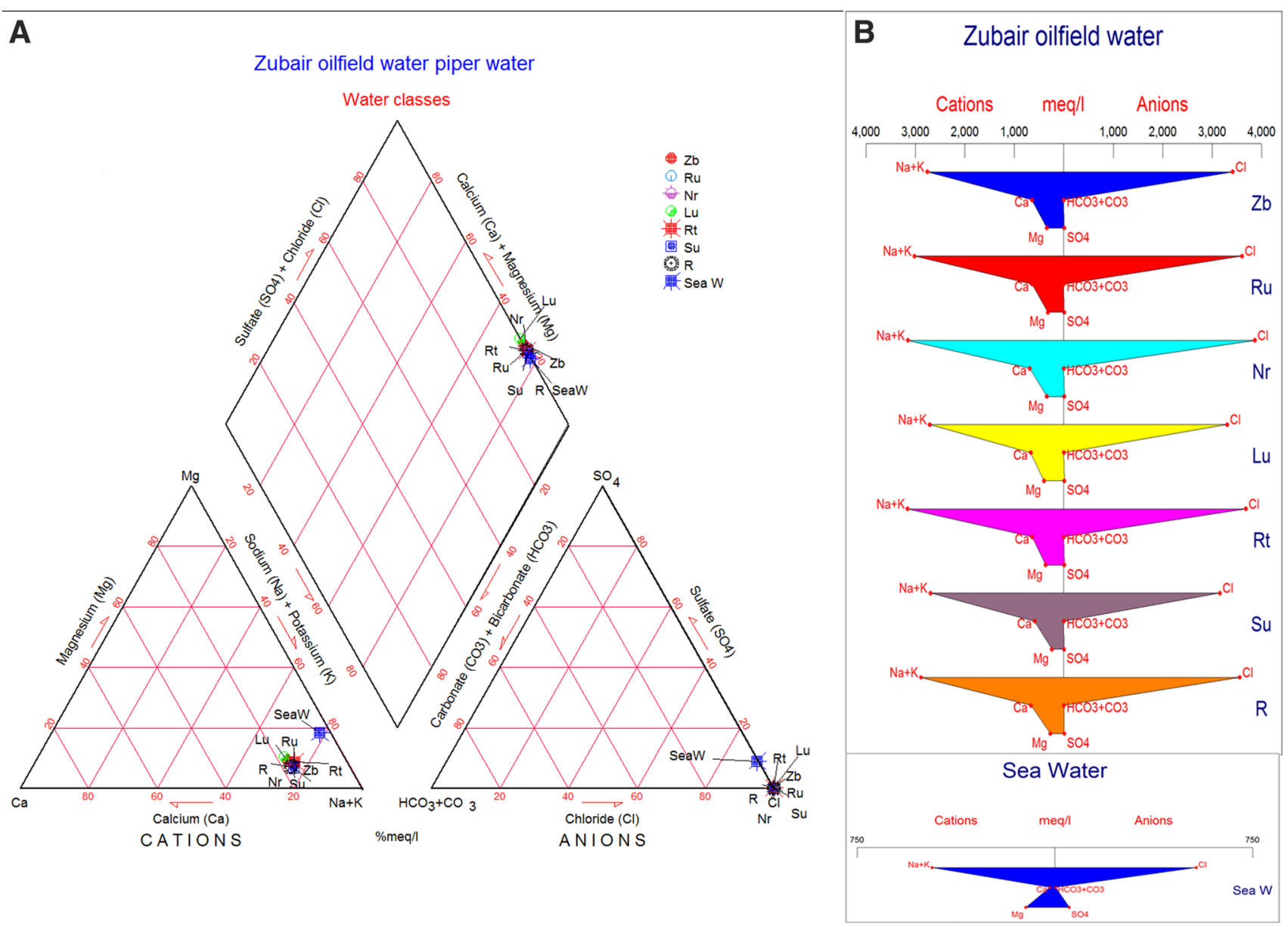

Fig. 5 Brine water types depending on a piper classification and $\mathbf{b}$ stiff diagram

Table 4 Mineral saturation index values of the Zubair brines in the oilfields studied

\begin{tabular}{llllrrr}
\hline Oilfield & Anhydrite & Aragonite & Calcite & Dolomite & Gypsum & \multicolumn{1}{c}{ Halite } \\
\hline $\mathrm{Zb}$ & -0.3229 & -0.5963 & -0.4489 & -0.8811 & -0.2035 & -0.6965 \\
$\mathrm{R}$ & -0.3272 & -0.2985 & -0.1510 & -0.3986 & -0.2146 & -0.6319 \\
$\mathrm{Ru}$ & -0.3065 & -0.7230 & -0.5756 & -1.1445 & -0.1974 & -0.6033 \\
$\mathrm{NR}$ & -0.2216 & -0.1344 & 0.0131 & 0.0314 & -0.1167 & -0.5596 \\
$\mathrm{Lu}$ & -0.1627 & -0.1711 & -0.0237 & 0.0114 & -0.0535 & -0.6052 \\
$\mathrm{Rt}$ & -0.3475 & -0.7639 & -0.6164 & -1.1840 & -0.2273 & -0.6971 \\
$\mathrm{Su}$ & -0.5354 & -0.3710 & -0.2236 & -0.5533 & -0.4119 & -0.7303 \\
\hline
\end{tabular}

liquid phase. Dolomite tends to be saturated in NR and $\mathrm{Lu}$, while in the Lu calcite may be precipitated forming calcareous scale. The potential salts that can be precipitated from the Zubair brines were hypothetically calculated to be as $\mathrm{NaCl}(76 \%), \mathrm{CaCl}_{2}(15 \%), \mathrm{MgCl}_{2}(7.5 \%)$, $\mathrm{Ca}\left(\mathrm{HCO}_{3}\right)_{2}, \mathrm{CaSO}_{4}$ and $\mathrm{KCl}$ together $1.6 \%$.

\section{Salinity}

It is best to measure the salinity ( $\mathrm{S} \%$ ) at the conditions of the oil well itself (Awadh, 2018); here, the salinity value has been computed according to Lewis and Perkin (1979) as below:

$S(\% \circ)=1.806 \mathrm{Cl}(\% \circ 0)$

The low salinity of fluids affects permeability of the reservoir. It may cause swelling of water-expandable clay which leads to increase in the clay dimensions and reduces the pore space and impedes the fluids movement. Clays are the cementing medium in many sandstone formations. Swelling weakens this cementation and releases the fine particles which cause plug (Borchardt and Yen 1989). The salinity 


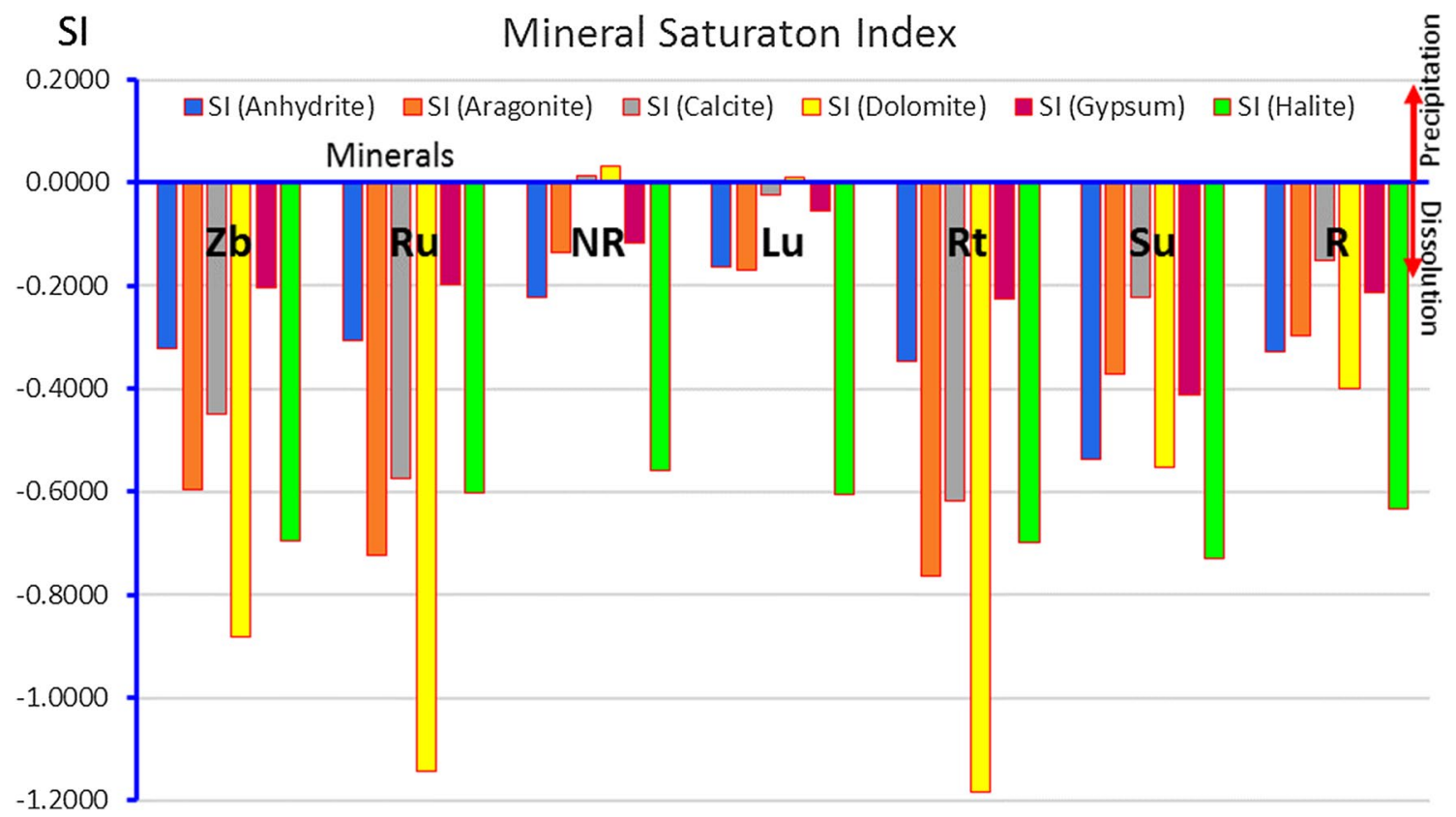

Fig. 6 Mineral saturation index illustrates the precipitate and dissolved mineral species in the Zubair brines

values of Zubair brines are presented in Table 1. The high salinity was recorded in $\mathrm{Lu}(257 \%$ o), while the low salinity (221\%o) was detected in Ru oilfields. The apparent water salinity (AWS) depended on the chloride value and is generally used to assess brine salinity. The water saturation $\left(S_{W}\right)$ was calculated from AWS by the equation stated by Tiab and Donaldson (2004):

$S_{\mathrm{W}}(\%)=\frac{\mathrm{AWS}}{\mathrm{TDS}}$

The equation of Afizu (2013) was applied to compute the hydrocarbon saturation $\left(S_{\mathrm{H}}\right)$ as follow:

$S_{\mathrm{H}}=\left(1-S_{\mathrm{W}}\right) \%$

The $S_{\mathrm{W}}$ for Zubair reservoir ranges between $0.59 \%$ in $\mathrm{Lu}$ and $0.61 \%$ in the other oilfields with average $0.60 \%$. The $S_{\mathrm{H}}$ ranges between $0.39 \%$ in Luhais oilfield and $0.41 \%$ in the other oilfields with average $0.39 \%$ (Table 1 ). The salinity can give an idea for predicting the direction of brine movement. The high salinity generates high pressure and accordingly brines may move toward low pressure. The brines in all oilfields studied were modeled by isosalinty maps as shown in Fig. 7, where this application had been employed by Awadh et al. 2018.

\section{Salinity origin}

The halides (chloride and bromide) are common solutes in the aqueous solution due to their ionic potential, and they have similar behavior in the environment. They are commonly used as geochemical tracers in the hydrogeological studies (Horner et al. 2017). The $\mathrm{Br}$ content and $\mathrm{Cl} / \mathrm{Br}$ ratio are used to differentiate the different origin of groundwater (Freeman 2007). They are used to identify the seawater brines and others that resulted from evaporite dissolution in sedimentary basins (Gupta and Rostron 2012). The average abundance of chloride and bromide in seawater is 19,000 $\mu \mathrm{g} / \mathrm{l}$ and $65 \mu \mathrm{g} / \mathrm{l}$, respectively (Edmund 2009). Both chloride and bromide are highly soluble; evaporation will leave residual brine rich in bromide after chloride solids (Davis et al. 2014). The seawater has relatively uniform $\mathrm{Cl}$ and $\mathrm{Br}$ concentrations and has a mean $\mathrm{Cl} / \mathrm{Br}$ mass ratio range of 284 to 293 (Eggenkamp 2014). The $\mathrm{Cl} / \mathrm{Br}$ ratio of a solution is defined as:

$R=C l / B r \quad$ (Horner et al. 2017)

As a result of the rock-water interaction, the salinity increases and the $R$ can also be utilized in the groundwater flow path identification and origin of oilfield brine (Carpenter 1978; Park et al. 2002). The $R$ value in seawater does not change by evaporation up the point when halite starts to precipitate at about roughly $(180,000 \mathrm{ppm})$ of $\mathrm{Cl}$ concentration (Walter et al. 2015). In the last stage of evaporation, as $\mathrm{Cl}$ precipitates the $\mathrm{Br}$ partitions and holds in the solution and precipitates in the $\mathrm{K}$ evaporitic halide minerals such as sylvite $(\mathrm{KCl})$ and carnalite $\left(\mathrm{KMgCl}_{3} \cdot 6 \mathrm{H}_{2} \mathrm{O}\right)$, while in the residual brine, it drops conspicuously to less than 44 in the residual brine (Taberner et al. 2000). Halite dissolution produces a rapid increase in $\mathrm{R}$. In the oilfield brines originated 

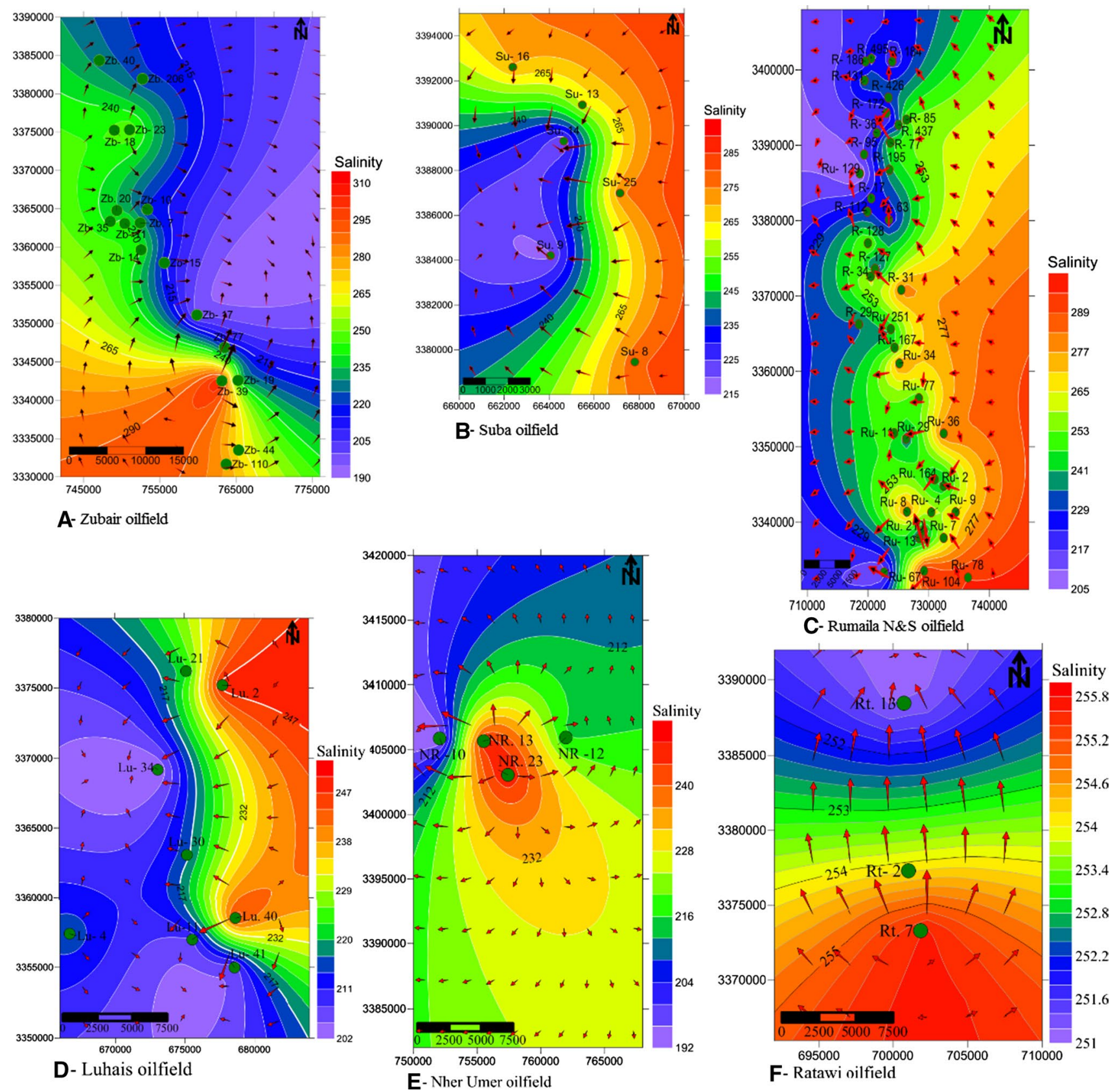

Fig. 7 Isosalinity map and probable flow path of a, Zubair, b Suba, $\mathbf{c}$ Rumaila N and S, d Luhais, e Nhar Umer, $\mathbf{f}$ Ratawi oilfields

from seawater which have very low concentration of $\mathrm{Br}$, the $R$ is typically $100-300$, although they can vary widely (Carpenter 1978; Vengosh and Pankratov 1998). Halite leaching and dissolution adds $\mathrm{Na}$ and relative $\mathrm{Br}$ having $R$ between one thousand and several thousand (Freeman 2007; Alcala and Custodio 2008). In the Zubair brines, $\mathrm{Cl}$ content ranges from 121,200 to $141,650 \mathrm{ppm}$ and $\mathrm{Br}$ ranges between 200 and $450 \mathrm{ppm}$ with an average of 131,067 and $360 \mathrm{ppm}$, respectively (Table 5).
The $R$ value of brines greater than that of seawater indicates the addition of chloride to the Zubair brines from another source. This is attributed to the dissolution of chloride from evaporates existing in other formations and then migrating to the Zubair. The formations overlain the Zubair Formation (Middle Cretaceous formation Ahmadi and Nahr Umr) are immature and had very little oil, while the Jurassic formations (Sulaiy, Najmah and Sargelu) are mature formation (Al-Ameri et al. 2011). The hydrocarbon in Zubair oilfield is mainly sourced from the deeper 
Table $5 \mathrm{Cl}$ and $\mathrm{Br}$ concentration (ppm) and $\mathrm{Cl} / \mathrm{Br}$ in the Zubair brines compared to the seawater

\begin{tabular}{|c|c|c|c|c|}
\hline Field & Well & $\mathrm{Cl}$ & $\mathrm{Br}$ & $\mathrm{Cl} / \mathrm{Br}$ \\
\hline \multirow[t]{3}{*}{$\mathrm{Zb}$} & Zb. 7 & 129,100 & 380 & 340 \\
\hline & Zb. 206 & 122,820 & 400 & 307 \\
\hline & Zb. 20 & 130,500 & 350 & 373 \\
\hline \multirow[t]{3}{*}{$\mathrm{R}$} & R. 437 & 127,250 & 200 & 636 \\
\hline & R. 495 & 129,350 & 380 & 340 \\
\hline & R-36 & 121,200 & 302 & 401 \\
\hline \multirow[t]{3}{*}{$\mathrm{Ru}$} & Ru. 164 & 132,570 & 355 & 373 \\
\hline & Ru. 251 & 133,675 & 380 & 352 \\
\hline & Ru. 210 & 129,500 & 410 & 316 \\
\hline \multirow[t]{2}{*}{ NR } & NR. 23 & 137,370 & 450 & 305 \\
\hline & NR. 13 & 136,450 & 390 & 350 \\
\hline \multirow[t]{2}{*}{$\mathrm{Lu}$} & Lu. 40 & 135,930 & 380 & 358 \\
\hline & Lu. 2 & 137,800 & 340 & 405 \\
\hline \multirow[t]{2}{*}{ Rt } & Rt. 7 & 141,650 & 373 & 380 \\
\hline & Rt. 13 & 139,100 & 385 & 361 \\
\hline \multirow[t]{2}{*}{$\mathrm{Su}$} & Su. 14 & 122,400 & 350 & 350 \\
\hline & Su. 9 & 121,480 & 300 & 405 \\
\hline Average & & 131,067 & 360 & 374 \\
\hline Max. & & 141,650 & 450 & 636 \\
\hline Min. & & 121,200 & 200 & 305 \\
\hline Seawater $^{\mathrm{a}}$ & & 19,000 & 65 & 288 \\
\hline
\end{tabular}

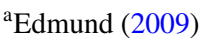

formations of Sargelu, Najmah and Sulaiy and mixed with the oil generated from the Zubair Formation itself (AlAmeri et al. 2011). The evaporitic formation Gotnia (U. Jurassic) overlain Sulaiy and underlain Sargelu and Najmah (Fig. 2). The Gotnia Formation is of shallow hyper lagoonal basin (Al-Hajeri and Bowden, 2017) forming a regional seal separating the Jurassic and the Cretaceous Formations (Al-Hajeri and Bowden 2017). Many preGotnia Formation faults detected by the seismic section (Fig. 8) may be a pathway of fluid passage (Al-Hajeri and Bowden, 2017). The brines moved upward through faulted zones in the Gotnia Formation whereby Jurassic and Cretaceous faults are connected (Fig. 8). For this reason, the brines passed through the Gotnia Formation and dissolve further halite resulting in the enrichment of chloride ion, and therefore, the $R$ ratio appears high. The hydrocarbons migrate by water movement (Selley and Sonnenberg 2016); this concept confirms that hydrocarbons had been migrated upwards from the source rocks (Sargelu Formation) and trapped in the Zubair reservoir through the fractures and cracks in Gotnia Formation.

\section{Conclusions}

Through the brine chemistry of the oilfields (Rt, Lu, Su, R, $\mathrm{Ru}, \mathrm{Zb}$ and $\mathrm{NR}$ ) within Zubair reservoir southeastern Iraq, the brief conclusions can be declared in the following points:

1. The ionic abundance in the brine, the Zubair reservoir is arranged as $\mathrm{Na}>\mathrm{Ca}>\mathrm{Mg}>\mathrm{K}$ and $\mathrm{Cl}>\mathrm{SO}_{4}>\mathrm{HCO}$. Sodium and chloride are predominated ions, where $\mathrm{Na}$, $\mathrm{Ca}$ and $\mathrm{Cl}$ ions compose of more than $97 \%$ of the total TDS; brines are predominated by $\mathrm{Na}$ (73.8 epm), Ca (17.5 epm), $\mathrm{Mg}$ (7.4 epm) and $\mathrm{K}$ (1.28 epm); and anion comprise of $\mathrm{Cl}$ (99.7 epm), $\mathrm{SO}_{4}(0.23 \mathrm{epm})$, and $\mathrm{HCO}_{3}$ (0.07 epm).

2. The $\mathrm{Na}, \mathrm{Cl}, \mathrm{Ca}$ and $\mathrm{Mg}$ contents are 6.34, 7, 34.3 and 2.59 times greater that seawater, respectively, while $\mathrm{SO}_{4}$ ion is relatively less.

3. The Zubair brines are expressed as unsaturated solutions as the mineral phases are existed in dissolving state with hypothetical salts represented by $\mathrm{NaCl}(76 \%), \mathrm{CaCl}_{2}$ (15\%) and $\mathrm{MgCl}_{2}(7.5 \%)$. The salts $\mathrm{Ca}\left(\mathrm{HCO}_{3}\right)_{2}, \mathrm{CaSO}_{4}$ and $\mathrm{KCl}$ are together formed only $1.6 \%$.

4. The Zubair brines are characterized by high salinity exceeding six times seawater, where the highest salinity (257\%o) was recorded in the Ru oilfield but the lowest $(221 \%$ ) was recorded in Lu oilfield, with average $237 \%$.

5. The Zubair brines in oilfields studied are of marine water developed in a confined basin dominate by $\mathrm{CaCl}_{2}$. The diagenesis processes participated in developing the brine salinity, particularly dissolving halite and anhydrite and moved upwards through the Gotnia Formation located underlain Zubair Formation. 
Fig. 8 Seismic section perpendicular to the anticline axis in the $R$ oilfield
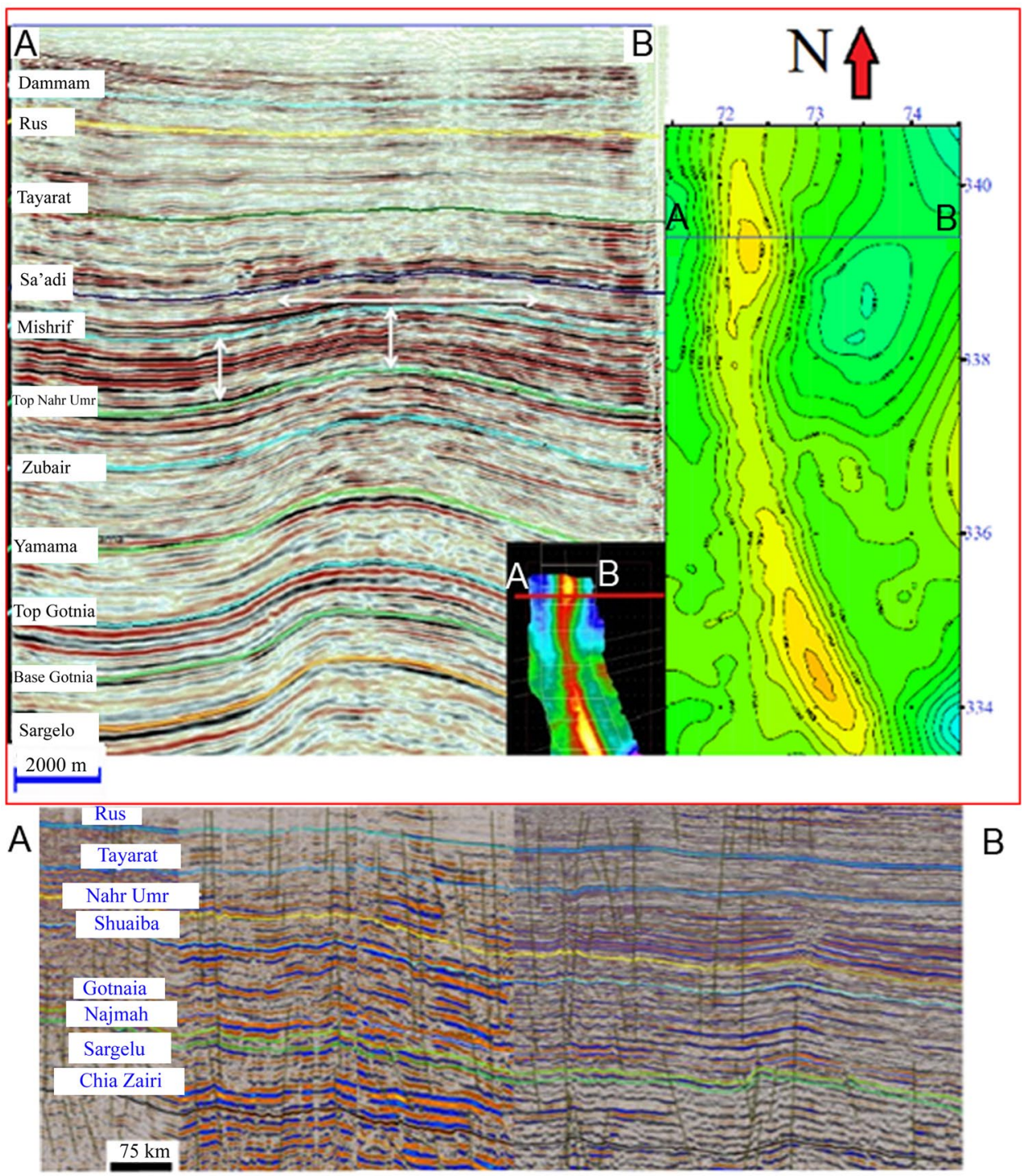

Acknowledgements This paper is a part of the $\mathrm{PhD}$ thesis that has been completed in the Department of geology, College of Science, University of Baghdad. Authors are grateful to the Basrah Oil Company (BOC) for providing us with the oilfield water samples and relevant data. Our appreciation is also sent to the Laboratory staff of the BOC for conducting the analysis of oilfield waters.

\section{Compliance with ethical standards}

Conflict of interest The authors declare no conflict of interest.

Open Access This article is distributed under the terms of the Creative Commons Attribution 4.0 International License (http://creativeco mmons.org/licenses/by/4.0/), which permits unrestricted use, distribution, and reproduction in any medium, provided you give appropriate credit to the original author(s) and the source, provide a link to the Creative Commons license, and indicate if changes were made.

\section{References}

Adams S, Titusa R, Pietersen K, Tredoux G, Harris C (2001) Hydrochemical characteristics of aquifers near Sutherland in the Western Karoo, South Africa. J Hydrol 241:91-103

Afizu M (2013) Determining the relationship between resistivity, water and hydrocarbon saturation of rock formation using composite well logs. Acad J interdiscip Stud 2(13):119-123

Al-Ameri TK, Pitman J, Naser ME, Zumberge J, Al-Haydari HA (2011) Programed oil generation of the Zubair Formation, Southern Iraq oil fields: results from Petromod software modeling and geochemical analysis. Arab J Geosci 4:1239-1259

Al-Atabi AN (2009) Hydrogeochemistry of Yamama Formation reservoir water and the over pressure estimation in selected oil wellsSouthern Iraq fields. Unpub. M.Sc. Thesis, College of Science, University of Basrah (in Arabic)

Al-Fares AA, Bouman M, Jeans PA (1998) New look at the middlelower cretaceous stratigraphy, Offshore Kuwait. GeoArabia 3(4):543-560 
Al-Hajeri MM, Bowden SA (2017) Application of formation water geochemistry to assess seal integrity of the Gotnia Formation, Kuwait. Arab J Geosci 10(56):1-10

Al-Husseini M (1997) Jurassic sequence stratigraphy of the western and southern Arabian Gulf. GeoArabia 2(4):361-382

Al-Sharhan AS, Nairn AEM (1997) Sedimentary basins and petroleum geology of the middle east. Elsevier, Amsterdam

Alcala FJ, Custodio E (2008) Using the $\mathrm{Cl} / \mathrm{Br}$ ratio as a tracer to identify the origin of salinity in aquifers in Spain and Portugal. J Hydrol 359:189-207

Ali AJ, Nasser ME (1989) Facies analysis of the L. Cretaceous oil-bearing Zubair Formation in Southern Iraq. Mod Geol 13:225-242

Aqrawi A, Goff J, Horbury A, Sadooni F (2010) The petroleum geology of Iraq. Scientific press Ltd., London

Awadh SM (2018) Physico-chemical characterization and salinity distribution of the oilfield water in the upper member of Zubair sandstones in Rumaila North Oilfield, Southern Iraq. Iran J Oil Gas Sci Technol 7(1):20-39

Awadh SM, Al-Mimar HS, Al-Yaseri AA (2018) Salinity mapping model and brine chemistry of Mishrif reservoir in Basrah oilfields, Southern Iraq. Arab J Geosci 11(18):552. https://doi.org/10.1007/ s12517-018-3908-5

Awadh SM, Al-Yaseri A, Hussein AR (2014) The influence of Kaolinite and $\mathrm{pH}$ on permeability in the Zubair reservoir in the North Rumaila Oilfield, Southern Iraq. Iraqi J Sci 55(2):780-789

Awadh SM (2012) AquaSal Chem-version 1. University of Baghdad, College of Science, Department of Earth Sciences. A series of software development in geochemistry

Borchardt JK, Yen TF (1989) Oil-field chemistry enhanced recovery and production stimulation. American Chemical Society, Washington

Brouwer DR, Jansen JD (2004) dynamic optimization of water flooding with smart wells using optimal control theory. SPE J (SPE 78278-PA) 9(4):391-402

Buday T Jassim SZ (1980) The regional geology of Iraq, stratigraphy and palaeogeography. State Organization for Minerals, Baghdad, Iraq

Carpenter AB (1978) Origin and chemical evolution of brines in sedimentary basins, Oklah. Geol Surv Circ 79:60-77

Collins AG (1975) Geochemistry of oilfield waters. Elsevier Scientific Publishing Company, Amsterdam

Davis SN, Fabryka-Martin JT, Wolfsberg LE (2014) Variations of bromide in potable in the United States. Ground Water 42(6):902-909

Edmund JM (2009) Seawater manual. Fundamentals of water chemistry for marine Aquarists. Distributed by United Pet Group, Inc

Eggenkamp H (2014) The geochemistry of stable chlorine and bromine isotopes. Springer, Heidelberg, Berlin

Faure G (1986) Principles of isotope geology. Wiley, New York

Fleischer M (1962) Recent estimates of the abundances of the elements in the earth's crust. United States Geological Survey Circular No. 285

Freeman JT (2007) The use of bromide and chloride mass ratios to differentiate salt-dissolution and formation brines in shallow groundwater of the Western Canadian Sedimentary Basin. Hydrogeol J 15:1377-1385

Giraud R, Maurin JC (1992) Early cretaceous rifts of Western and Central Africa: an overview. Tectonophysics 213:153-168
Gupta I, Rostron BJ (2012) $\mathrm{Cl} / \mathrm{Br}$ compositions as indicators of the origin of brines: hydrogeologic simulations of the Alberta Basin, Canada. GSA Bull 124(1-2):200-212

Horner KN, Michael SA, McPhail DC (2017) Chloride and bromide sources in water: quantitative model use and uncertainty. J Hydrol 549:571-580

Ibrahim IA (2001) Geological study and oil prospectively for Zubair Formation. OEC, unpublished report

Jafar MS (2010) Hydrocarbon source and oil accumulation in Cenomanian: early Turonian Mishrif Formation reservoir, in selected fields, Southeastern Iraq. Ph.D. Thesis, University of Baghdad

Jassim SZ, Goff JC (2006) Geology of Iraq. Published by Dolin, Prague and Moravian Museum, Brno

Lewis EL, Perkin RG (1979) Salinity-its definition and calculation Frozen sea research group, Unpublished manuscript, Pacific Marine Science Report, pp 28-76

Mason B (1966) Principles of geochemistry. Wiley, New York

Park J, Bethke CM, Torgersen T, Johnson TM (2002) Transport modeling applied to the interpretation of groundwater ${ }^{36} \mathrm{Cl}$ age. Water Resour Res 38(5):1-15

Rao NS, Rao PS (2010) Major ion chemistry of groundwater in a river basin: a study from India. Environ Earth Sci 61:757-775

Selley RC, Sonnenberg SA (2016) Elements of petroleum geology, 3rd edn. Academic press, London

Sharland PR, Archer R, Casey DM, Davies RB, Hall SH, Heward AP, Horbury AD, Simmons MD (2001) Arabian plate sequence stratigraphy. Geo Arabia Special Publication 2

Taberner C, Cendo DI, Pueyo JJ, Ayora C (2000) The use of environmental markers to distinguish marine vs. continental deposition and to quantify the significance of recycling in evaporite basins. Sediment Geol 127(3-4):213-240

Tiab D, Donaldson EC (2004) Petrophysics, 2ed, theory and practice of measuring reservoir rock and fluids transport properties. Gulf professional publishing, Oxford

Van Bellen RC, Duningotn HV, Wetzel R, Moroton DM (1959) Lexique Stratgraphique International, Asia, Facicula; Tenth A. Iraq, Center National de la Recherché Scientifique, Paries

Vengosh A, Pankratov I (2005) Chloride/bromide and chloride/fluoride ratios of domestic sewage effluents and associated contaminated ground water. Ground Water 36(5):815-824

Walter LM, Stueber AM, Ted JH (2015) Br-Cl-Na systematics in Illinois basin fluids: constraints on fluid origin and evolution. Geology $18: 315-318$

Zaporozec A (1972) Graphical interpretation of water quality data. Ground Water 10(2):32-43

Ziegler M (2001) Late Permian to Holocene paleofacies evolution of the Arabian Plate and its hydrocarbon occurrence. GeoArabia $6(3): 445-504$

Publisher's Note Springer Nature remains neutral with regard to jurisdictional claims in published maps and institutional affiliations. 